\title{
Capital Comes North: Exploring the Discursive Challenges to International Solidarity among Nickel Miners in Sudbury, Ontario
}

\author{
Adam D.K. King, York University, Canada
}

\begin{abstract}
This article draws on twenty-six qualitative interviews with rank-and-file United Steelworkers nickel miners in Sudbury, Ontario. It analyses some of the challenges to building international solidarity at Brazilian-based multinational mining firm Vale. Engaging with labour geography and labour movement renewal scholarship, the article explores how identity formation and institutional structures interact to shape workers' understandings of their interests and capacities. In particular, it considers the impact of national identity as it arose in response to the issue of foreign ownership during the interviews. The findings suggest that attempts by the union to discursively reframe workers' struggle against their new multinational employer have yet to fully contend with the persistence of spatially bound forms of working-class identity and interests among workers in the sample.
\end{abstract}

\section{KEYWORDS}

international solidarity; discursive framing; spatial interests; national identity; nickel mining

\section{Introduction}

This article contributes to discussions concerning the prospects of and impediments to building international solidarity through an analysis of qualitative interviews with nickel miners in Sudbury, Ontario. It addresses working-class identity within a socio-political context in which unionised workers face a new multinational employer hostile to its unionised workforce. Based on a case study with twenty-six United Steelworker rank-and-file union members employed at Brazilianbased mining multinational Vale, the article speaks to two relevant scholarly literatures. On the one hand, it addresses work in the area of labour geography, which deals with the spatial organisation of investment and production (Herod, 2001; Silver, 2003; Harvey, 2006; Ellem, 2016). On the other hand, it engages with research on union renewal and organising strategy (Bronfenbrenner and Juravich, 1998; Fantasia and Voss, 2004; Lévesque and Murray, 2010). It uses this material to analyse workers' narratives about union efforts to build solidarity with Vale workers in the Global South during Vale's 2006 takeover of mines in Sudbury, and during and after a year-long strike in Sudbury in 2009-2010 (Peters, 2010). The article asks: what particular subjective challenges arise during union efforts to build international solidarity among workers in the Global North with a long history of union militancy?

Labour geographers and sociologists have debated the extent to which the increasing global integration of capitalist economies weakens, reorganises or augments working-class power and agency (Tilly, 1995; Herod, 2001; Evans, 2010, 2014). In literature on union renewal - whether focused on global labour issues or not - others have identified member mobilisation, internal 
union solidarity and extra-union alliances as key aspects of labour movement revitalisation (Lévesque and Murray, 2002, 2010; Ross, 2008; Black, 2018). Yet, too little research has brought these two literatures together, particularly to better understand the impacts of global integration on working-class identity and organising (Frundt, 2005 is a notable exception). By utilising a case study of workers in an especially spatially fixed industry, which has recently undergone a foreign takeover, this article's contribution is to show how place-based identities may simultaneously cohere durable - yet at times problematic - forms of collectivity while hindering efforts to build solidarity between workers across borders. In particular, the article draws on research which highlights the importance of discursive framing in union campaigns (Frundt, 2005; Lévesque and Murray, 2010; Hrynyshyn and Ross, 2011) for clues about how particular institutional arrangements within unions, and between unions and nation-states, shape workers' conceptualisations of their interests.

Nickel mining in Sudbury offers an illuminating case through which to explore these issues. First, because of mining's relative spatial fixity, the industry tends to be less vulnerable to production outsourcing and other forms of "global labour arbitrage" (Brecher, Costello and Smith, 2006: 9). Although there is debate about the extent to which global integration and capital concentration have reduced mining's relative insulation from the "spatial fix" (Silver, 2003), when compared to manufacturing, mining undoubtedly remains far less susceptible to capital flight and the spatial reorganisation of production (Ellem, 2016). Under circumstances with lower levels of direct labour competition from workers in other countries, we would expect to find less resistance to organising international solidarity strategies. As the interview data analysed below suggests, however, the issue is more nuanced.

Second, Brazilian-based multinational Vale's acquisition of the International Nickel Company (Inco) in 2006 is emblematic of a relatively new phenomenon wherein firms or large sources of capital migrate from the Global South to the Global North (Fontes and Garcia, 2014; Marshall, 2015). In Canada's case, this has been especially prevalent in resource extraction sectors of the economy (Stanford, 2008), though the effects on working-class organisation and identity remain understudied. Vale's place in Canada suggests a need to study the practices of Global South corporations as they pursue accumulation strategies on a global scale and acquire extractive and productive assets in North America and Europe. The movement of Southern capital into the Global North thus points to the need to explore the international connections between national labour movements and union members.

Lastly, Vale's quite aggressive labour relations approach (Aguzzoli and Geary, 2014) which, combined with the 2008 financial crisis, precipitated a year-long strike in 2009-2010 (Peters, 2010; King, 2017), also provides an auspicious and pressing context within which to analyse a sample of workers' attitudes and ideas about international solidarity in their industry and union.

\section{Labour Geographies and Mining}

Researchers spanning political economy, economic and labour geography, and the sociology of work have studied the tendency of capital to relocate in response to various crises, in the process transforming the social relations of production and reproduction (Cowie, 1999; Silver, 2003). Labour scholars have intervened in these debates to more fully elucidate the ways in which workers and their organisations shape the geography of capitalism through their resistance to capital (Herod, 2001). The agency of workers and working-class institutions has thus emerged as a central factor within scholarship on the spatial dynamics of capitalism.

Although labour is widely recognised as an agent in the geography of capitalist social 
relations, capital mobility has called labour's relative strength into question. Neo-liberalism, deindustrialisation in regions of the Global North and the global integration of manufacturing supply chains have sparked debate about the contemporary health and strategic capacity of labour movements the world over. Where some scholars see globalisation weakening national labour movements, particularly in North America and Western Europe (Tilly, 1995; Burawoy, 2010), others identify strategic openings (Evans, 2010). From the former perspective, downward wage pressure and labour market competition across an unevenly developed capitalism arise as especially significant challenges. Moreover, some authors point to the ways in which national institutional frameworks place constraints on the types and level of disruption in which unions can engage, and thus the ways that such institutional constraints might limit coordination across countries or legal jurisdictions (Bolsmann, 2010; Munck, 2010). Evans (2010, 2014), on the other hand, has argued that the global integration of economies generates structural opportunities for labour. Precisely because of the ways that neo-liberalism has weakened labour at the national level, he claims, global labour connections have tended to grow and draw "synergistically" (Evans, 2010: 260) on national differences. Herod (2001), relatedly yet distinctively, draws the conclusion that global solidarity is not necessarily the strategy in which unions must engage. According to him, calls for general international labour solidarity lack contextual specification. In some instances, the organisation of global capital necessitates that labour attempt to respond at a comparable geographic scale. Yet, in other cases, global interconnections may enhance the strategic sensitivity of particular localities. Whether to pursue global labour coordination or to capitalise on local sites of strength will be case-specific and require ongoing analysis, according to this view. Such considerations are particularly relevant with respect to nickel mining in Sudbury (Leadbeater, 2008), especially given the Brazilian origins of Vale and the dynamics of class and national identity at play.

Researchers have also turned their attention to other forms of global solidarity campaigns and organisational initiatives, such as boycotts and attempts to influence the labour policies of multinational corporations (Seidman, 2009), international framework agreements (Thomas, 2011) and global union federations (Cotton and Gumbrell-McCormick, 2012; Filho and Silva, 2019). Although such organisations and initiatives often represent necessary innovations aimed at meeting the challenges of globally coordinated corporate interests, research suggests that sympathetic governments and engaged, nationally based unions are necessary to render such approaches impactful. Moreover, some posit that the scale of global coordination makes mass member involvement difficult (Cotton and Gumbrell-McCormick, 2012), leading to failures and lost opportunities to connect with local union organising campaigns (Thomas, 2011). However, this research has tended to focus on the institutional and practical impediments to global solidarity and collective action, and has thus devoted less space to issues of worker subjectivity, class and national identity and their place in union organising strategies.

As Ellem $(2006,2016)$ has shown, mining offers a rich industrial context within which to explore the spatial dynamics of capitalism and the prospects and challenges of global labour solidarity. Mining is simultaneously global and local, perhaps especially so. The capital-intensity of the industry necessarily entails ownership by large, often transnational, corporations embedded in global financial markets (Deneault and Sacher, 2012). Yet, the materiality of ore bodies fixes capital in place in ways that encourage mining firms to look for alternative means through which to discipline labour and contain costs, frequently via "technological fixes" (Silver, 2003) in the production process. What requires further study, however, are the ways that the local fixity of mining shapes worker subjectivity, and how this affects efforts to mobilise members during campaigns aimed at building international solidarity. 


\section{Union Renewal, Workers' Interests and Discursive Framing}

For some time, labour researchers studying "union renewal" or "labour movement revitalisation" have been reflecting on how unions can reverse what have now become decades of decline (Bronfenbrenner et al., 1998, and Kumar and Schenk, 2005, are illustrative collections). Although plenty of insightful work has been produced, unions remain in a state of crisis in much of North America (Camfield, 2011). Alongside research on union strategy has been a growing body of work specifically focused on global union activity (Johns, 1998; Anner, 2011). The coincidence in these literatures stems at least in part from the confluence of union decline and capitalist globalisation. Labour movements have needed to rethink organising strategy as well as their relationship to workers and unions in other countries, often simultaneously. Member mobilisation is a key theme running through much of this work. For some, the emphasis has been on "social unionism" (Ross, 2008), connecting workers' struggles inside and outside the workplace, or what McAlevey (2016) refers to as "whole worker organizing". Relatedly, other authors focus on the internal democracy of unions as an indispensable mechanism for the mass participation of rank-and-file workers, and thus for union renewal (Lévesque and Murray, 2010). The emphasis on member mobilisation and internal union democracy, however, can raise thorny questions concerning the scope of workers' interests and the factors shaping workers' identities, particularly when considered within the context of building and coordinating international solidarity.

Johns (1998) makes a helpful theoretical distinction between what she refers to as workers' class and spatial interests. She writes: "Workers may have class interests that they share with workers across international borders, and spatial interests that divide them. In reality, there is a conflict between these interests that makes building a truly global movement problematic" (Johns, 1998: 255). Class interests, in this sense, abstractly denote all workers' relationships to owners of capital, whereas spatial interests involve the material concerns of workers as they are experienced across the uneven terrain of capitalist space. Johns elaborates on this distinction by distinguishing between "accommodationist solidarity" and "transformatory solidarity". In the former, workers (usually in the Global North) who have won spatially restricted material gains seek protection from the labour market competition of workers in less developed regions of the world. Workers engaged in accommodationist solidarity, as Cotton and Gumbrell-McCormick (2012) also suggest, often view the organisation of workers in less developed countries as primarily a protective measure. By reducing the appeal of the lower wages of workers in the Global South, workers in the industrial North can, ostensibly, prevent or mitigate capital flight. Transformatory solidarity, on the other hand, entails a project of identifying and strengthening working-class interests across space. Universal class interests in this latter form of solidarity dominate over spatially restricted interests (Johns, 1998: 255-9).

Yet, workers' interests are not statically determined by their geographical attachments or separations. The dynamic construction of working-class capacity and action is also shaped in the process of organising. Transforming workers' social identities is a central component of organising strategy. As Hrynyshyn and Ross (2011) emphasise, the way unions frame workers' identities and interests influences what workers believe are desirable goals and the necessary strategies to attain them. Seeliger (2016: 64), for example, considers the role of social memory in the "cross-border coordination of labour politics". He also shows how national institutional and regulatory frameworks shape workers' perceptions of effective union strategy. Workers evaluate courses of action and the possibilities for success based on past experiences, which are, inevitably, shaped by how national and local institutions and class struggle interact. The ways in which past institutional relations have structured class interests and regularised union activity 
continue to influence how workers understand their current confrontations with employers, as well as the available repertoires of collective action which they might utilise to redress their grievances.

Less well understood, however, are the ways that national and local institutions (unions, labour laws, governments) have contributed to durable forms of working-class identity and the ways these affect union campaigns aimed at building international solidarity among rank-and-file members. Although there has been reflection on the problems of sectionalism in the labour movement, perhaps most clearly through Harvey's (1995) elaboration of the problem of "militant particularism", less attention has been paid to the ways that locality, institutional context and union history continue to shape workers' identities.

\section{Mining in Sudbury, Ontario}

Underground miners and workers in the refining and processing facilities at Vale's (previously Inco's) operations in Sudbury are members of the United Steelworkers (USW) Local 6500. The USW, certified in 1962 after a drawn-out fight with the Communist-affiliated International Union of Mine, Mill and Smelter Workers (Mine-Mill), has represented workers through a series of profound structural and institutional changes in the mining industry, locally, nationally and globally.

Over the 1960s and 1970s, Local 6500 managed to win impressive gains for its members, in the process bargaining significant wage increases, extended health benefits and, eventually, a defined-benefit pension plan. As global economic contraction set in during the 1970s, however, Inco began to feel the squeeze of costly collective agreements coupled with decreased global nickel demand and consumption (Swift, 1977). Given the spatial fixity of Sudbury's mineral deposits and mining infrastructure, the company pursued substantial workforce reductions through an intensive project of labour process innovations. In 1971, employment at Inco, and USW 6500 membership, peaked at 18 224, after which it rapidly declined (United Steelworkers of America, 1987). By 1986, when the Steelworkers commissioned researchers to study the impact of new mining technologies, employment at Inco had fallen to 6518 , down 63 per cent from its peak fifteen years earlier (United Steelworkers of America, 1987: 3.3). By the 1990s, mechanisation and automation were extensive throughout the mines and refining facilities (Hall, 1993), leading one commentator to describe the local workforce as "unrecognizable" (Buse, 1993: 277). Brazilian-based Vale then purchased Inco's operations in 2006 amid a rush of investment into Canadian extractive industries related to the early-to-mid 2000s commodity boom experienced by many states with large resource extraction sectors (Stanford, 2008). Though Inco had previously restructured its Canadian operations and was quite profitable, Vale's takeover represented a new logic of financialisation with a greater focus on short-term profitability (Leadbeater, 2008; Peters, 2010). When Vale assumed control of Inco's Sudbury operations, just over 3000 workers remained at the mines (Saarinen, 2013: 165), in a city and surrounding area of roughly 164000 people (Statistics Canada, 2016).

Vale's takeover was in some respects a culmination of several decades of growing global capital concentration in the nickel mining industry (Leadbeater, 2008). As Inco sought to roll back the material gains and structural power of its unionised workforce over the 1970s and 1980s, it also pursued various strategies to diversify its resource base and globalise its operations. As global nickel consumption started to slow beginning in the late 1960s, Inco and other firms looked for lower-cost sources of ore outside of the industrial North. In some cases, bringing these new sites online exacerbated what developed into a persistent oversupply problem and 
placed further downward pressure on the price of nickel (Swift, 1977). Yet, by investing new capital abroad and integrating these production sites into their global operations, Inco sought to evade labour costs and environmental regulations in Canada and, ultimately, to control nickel supplies. However, global diversification in the 1970s initially failed to solve the company's profitability woes or prevent other firms from undermining its near monopoly position. Whereas Inco had supplied nearly 90 per cent of world nickel in 1950, its contribution had dropped below 20 per cent by 1985 (United Steelworkers of America, 1987: 4.7). Inco thus faced an even greater incentive to flexibilise its workforce through labour-saving technologies and the expanded use of non-union contract firms and workers (Leadbeater, 2008).

The combination of international competition, the global movement of capital, and deregulation of labour and environmental protections had deeply transformed the industry by the late 1990s, along with Inco's place within it. Foreign investment grew and full takeovers ensued in Canadian extractive sectors through the mid-2000s, as commodity prices soared and the stock valuations of resource companies followed suit (Stanford, 2008; Peters, 2010). New foreign investment was, however, only a brief reprieve for beleaguered workers in Sudbury. Amid the spreading contagion of the 2008 financial crisis, Vale reneged on the "no lay-offs" promise it had made during the final stages of its takeover and restructuring of Sudbury's mines in October 2006 (Brasch, 2010). When Vale and the USW entered bargaining in late 2008, it was clear that the company expected far-reaching concessions in the next collective agreement. After pushing the union into an ultimately unsuccessful year-long strike in 2009-2010, Vale was able to impose a two-tiered retirement system which ended new defined-benefit pensions, increased the use of contract workers and capped the "nickel bonus" (a productivity-based profit-sharing scheme) (Peters, 2010: 74-5). The company quickly recovered from the losses incurred during the Great Recession, and continued with its project of strategic global investment and "margins over volume" in its international operations (Vale, 2018: 5).

During the ownership transition and the prolonged strike over the 2010 contract, Local 6500 and the national and international arms of the Steelworkers union attempted to build upon existing global solidarity networks, particularly through linkages with unions representing Vale workers in the Global South (in Brazil, Mexico and Mozambique in particular), and to enhance the strategic capacities of workers employed and affected by Vale internationally. ${ }^{1}$ In the course of the 2009-2010 strike, the Steelworkers convened a conference in Sudbury with international labour leaders representing workers at Vale (Brasch, 2010). In some respects, the union built on pre-existing global linkages. However, given the new circumstances into which USW 6500 was entering (that is, facing a multinational employer with a global workforce), strategic efforts were made to strengthen the bargaining position of Canadian workers through international solidarity efforts (Brasch, 2010). The campaign and conference aimed to build upon global linkages and, as one worker interviewee put it, to "get going with that international solidarity stuff", at a time when the union and workers in Sudbury were locked into a particularly difficult battle.

\section{Methods}

In total, twenty-six workers ${ }^{2}$ were interviewed between January 2015 and July 2018 during

\footnotetext{
${ }^{1}$ For example, the USW is part of an international Gerdau Unity Council (addressed mostly at the operations of multinational firm Gerdau) in which the Brazilian Metalworkers' Union (CMN) is heavily involved. The international federation has engaged in several successful internationally coordinated actions to aid locked-out workers, most notably in Beaumont, Texas (Needleman, 2008: 82-4).

${ }^{2}$ To protect confidentiality and anonymity, all interviewees are referred to using pseudonyms.
} 
fieldwork for this research project. Interviews lasted between 45 and 120 minutes, with most taking approximately 90 minutes to complete. Participants ranged in age from 26 to 74 years, with an average age of 48.2, and only one worker (age 45) falling between 38 and 49 years of age.

Interviewees were all "white", though some retain ethnic, linguistic or cultural affiliations that they expressed as meaningful to their identities, particularly French-Canadian and Scandinavian heritages. This is reflective of Sudbury more broadly. In contrast to Ontario as a whole, where visible minorities account for 29.3 per cent of the total population, in Sudbury visible minorities represent only 6 per cent of the population (Statistics Canada, 2016). As we will see below, racialised notions of national identity shape how workers understand the changing nature of class conflict in Sudbury.

Interviewees were also all male. Though the lack of female miners is a limitation in terms of the representativeness of the sample, it is also important to note that male dominance in both the industry and the union has been a persistent problem which has shaped the ideology and orientation of rank-and-file members. Understanding this dynamic remains essential to grappling with working-class identity in Sudbury (King, 2019).

Finally, I intended this research to focus on rank-and-file workers, not elected union officials. Though attentive to the relationships between union structures, institutional forms and working-class identity, this research aimed to explore the identities of workers more broadly, and not simply those of elected representatives. Of the sample of interviewees, only five had ever held a position in their union local. Four had held health and safety committee positions, and one was previously elected to an executive leadership position.

Interviewees' career histories were also quite representative of other dynamics in the nickel mining industry. Seven (all under age 38) had previously worked for non-union, contract firms before gaining full-time, unionised employment at Inco-Vale. This pattern exemplifies the spread of precarious employment alongside the growth of contract mining supply and service firms in Sudbury (Robinson, 2005). Six interviewees were retired at the time of being interviewed, while seventeen had a family member who currently or at some point had worked at the mines. Moreover, twenty interviewees had strike experience, while thirteen had been on strike in 20092010.

Although interviews covered a range of topics and issues - and were conducted in an openended, oral history style (Bischoping and Gazso, 2016) - the analysis below deals with those questions and exchanges addressing international solidarity, foreign ownership and union organising strategy. These were prominent themes throughout the interviews, unsurprisingly given the still recent labour conflict of 2009-2010 and the largely acrimonious relations with Vale since 2006.

\section{Spatial Interests, Class Identity and International Solidarity}

The following sections explore narratives about class and spatially based identities as they emerged in workers' interviews. The findings demonstrate the uneven and at times contradictory ways in which workers drew upon ideas about space, place and belonging when discursively positioning themselves as individuals and members of the working class. In their narratives about union history and the contemporary challenges of international solidarity, workers made a series of shifting inclusions and exclusions. Union efforts to respond to socio-economic change and to address the difficulties presented by capital concentration and foreign ownership were at times met with worker resistance. Workers positioned the workplace and community changes brought on by foreign ownership - but also by union campaigns for international solidarity - as disruptive 
to the union and industrial relations institutions against which they understand themselves as a collective of workers.

Vale's takeover has also generated a rupture in the intergenerational production of workingclass identity as workers attempt to respond to a new set of ownership and managerial relations that seem to map class conflict onto national distinctions. Union efforts to discursively reframe class conflict, broaden workers' allegiances and make institutional connections with unions in the Global South, while admirable, have thus produced mixed responses from the workers interviewed during this research. Union leaders' discursive framing of Vale as a common enemy, and as a corporation bent on profit maximisation at any cost no matter the location, clashed with workers' understandings of their spatial interests, discourses of national identity which draw on problematic notions of the "foreignness" of Global South workers, as well as workers' attachment to historically effective yet spatially limited, repertoires of collective action. Ultimately, while USW continues to pursue international solidarity work alongside national and local organising, a less confrontational bargaining relationship with Vale has more recently emerged - raising questions about the future of the Local's global solidarity efforts.

\section{Class identity and spatial interests}

How interviewees characterised the development of their union, and the social bonds that sustain it, were strongly connected to the ways they described the historical and spatial organisation of class conflict in Sudbury. Especially for workers employed at Inco before the takeover, the previous owner's place in the community and the legacy of class conflict throughout its tenure influenced workers' understandings of contemporary class relations. Interviewees fit Inco into their narratives in distinct ways, often emphasising regionalised class opposition between Inco "bigwigs mostly in Toronto" (Dale, age 55) and workers in Sudbury. In this sense, class identity was spatialised historically, most notably along a "metropole-hinterland" (Dunk, 2003) divide quite regional to Ontario.

For workers in the sample, Sudbury's regional working-class history was an integral part of their conception of self and collectivity. Alain's (age 56) characterisation was typical:

For miners, I think, the idea of being workers and the image of Sudbury are very close. Sudbury is about mining, you know what I mean? Historically, this is true. When you work there, or your family members work there, it's a huge part of your identity ... You know about this strike, or that strike, how this thing or that thing was won. Then you think, this stuff has been important to the whole community. Like, you know, some businesses would close up to help the workers on strike at Inco. So when a strike happens, like last time [2009-2010], it feels to me like there's a lot to stand up for.

Alain went on to discuss the ways he felt that being a union member connected him to the community. He felt that the strong feelings "guys have about this town and mining" contributed to the strength of the union and workers' historical legacy of "fighting back when the time came".

Although such remembrance can at times slip into nostalgia when the past of "Canadian" ownership is expunged of its class antagonisms (particularly when contrasted with the immediate actions of Brazilian-based Vale), the forms of class identity and union organisation bred of the mid-to-late twentieth century continued to shape the ways workers articulated their interests. Strong community ties help to explain the reproduction of class identity among workers in the sample. In many respects, this is a variation on a theme many social historians have identified when new capitalist social relations come into conflict with established ways of cultural, 
economic and political life (Calhoun, 2012). However, as the interview data demonstrate, this is not only a process confined to the past formation of segments of the working class, but also a feature of class identity's reproduction. That is, place-based identities can continue to influence how workers understand their class position and their interests. Yet, the role that place and tradition play in the making of working-class identity poses challenges for re-imagining solidarity beyond the bounds of community or nation when capitalist globalisation necessitates this.

As Needleman (2008: 88) summarises:

While workers understand the connection between the local and global when it is explained to them, the impact of global efforts seems so far away that unless you are in a ... situation where the international support appears in your union hall, skepticism and even cynicism have a tendency to take root.

Even when fellow workers from abroad appear in the union hall, this proximity may not displace workers' long-term place-based identifications. Many workers - even one who had previously held an executive position - spoke of international labour conferences and meetings with hesitation in some instances and impatience in others. The former union leader, for instance, remarked:

I used to go to a lot of these conferences, events. We had guys from all over - Brazil, Africa, Mexico. It produced some good stuff. You got a sense of how things were all over the world. But eventually I got fed up. I said, 'We come here every year and we talk a lot of shit, about solidarity, about the workers, this and that'. But I said, 'When are we gonna act?' Right? Like, a lot of talk is good, but eventually it has to lead somewhere.

For this worker, global conferences and worker exchanges, while informative and motivating, ultimately proved frustrating as their potential was obstructed by the structural impediments to coordinated action across space. Moreover, how to frame the significance of such global exchanges to fellow workers was also challenging. He remarked:

For a lot of the guys, you know, it's hard to imagine what international solidarity means, practically. Like, okay, we can say we believe in it, but what do we do with that? (emphasis his).

As Frundt (2005), Hrynyshyn and Ross (2011) and others argue, how unions discursively frame issues and campaigns is an important component of mobilisation. Yet, what we might call reframing must contend with workers' established ways of seeing the world and their place within it, particularly with respect to forms of identity and interests which are quite spatially bound. These insights are particularly instructive when considering the processes through which relatively privileged workers in the Global North have collectively forged working-class identities over several decades or generations, and the ways that this erects obstacles along the path toward international solidarity. Moreover, such subjective issues are further compounded by the ways that institutionalised (national and sub-national) patterns of class conflict (and collaboration) limit what workers imagine can be accomplished through international solidarity.

\section{Foreignness and accommodationist solidarity}

How workers relate to globalisation, it has been suggested, is tied up with their geographic position in the economy (Herod, 2001). Workers who face competition from imports, or who are threatened with production outsourcing, will tend to look less favourably on global economic 
integration than those working in industries less subject to foreign competition. However, there is also a need to take stock of the subjective and ideological influences on workers' thoughts about globalisation. Political discourse which scapegoats immigrants, migrants or racialised workers in other countries can have an impact on how workers interpret their own challenges at work even if those challenges are not the direct outcome of competition with Global South workers. In other words, the material organisation of global capitalism influences how workers understand their interests in the global economy and the courses of action they feel they can pursue. Subjective, ideological and discursive factors must also be considered for the ways these shape working-class attitudes and action. During a period of rising right-wing populism, this is especially important to consider (Thomas and Tufts, 2016; Kellogg, 2019).

Brazilian conglomerate Vale's takeover of Inco has raised anew issues concerning globalisation and international competition in the mining industry (Leadbeater, 2008; Peters, 2010). For workers in this study, new foreign ownership at work has also problematised class identity, leading interviewees to emphasise their Canadian nationality in ways that they did not when discussing their former employer. For instance, interviewees deployed narratives about nationality and citizenship as a means of both explaining and criticising Vale. Workers used their "Canadian-ness" to mark their deservedness of respect, simultaneously characterising Vale as not caring about the standards of labour in Canada. Peter (age 50) summarised:

They basically thought that coming in here, they could just do as they like, basically treat us like they treat their own workers in Brazil, and that we would have to accept that. But this is Canada. That's not how things work here (emphasis his).

As the place identified with ownership has shifted from Toronto to Brazil, workers articulate class opposition in their narratives along national rather than regional lines, which often includes disparaging comments about Vale workers in the Global South.

For some workers, forms of national chauvinism ignited by the bitterness of the 2009-2010 strike thwart the prospect of international solidarity. During the interviews, these workers sometimes drew on implicitly racialised conceptions of distinction between themselves and Vale workers in other countries, and described Vale's labour relations as resulting from a "Third World" approach to work and employment. Doug (age 65) asked,

You musta seen the signs, or photos of 'em, from the strike? 'Vale, go back to Brazil', that type of thing?

However, in contrasting the company's supposedly foreign standards and ethics to their own, interviewees also positioned workers in the Global South as passively accepting poor treatment by their employers. Yves (age 28) predicted,

It's gonna be like over in China when a mine collapses and hundreds of people die. That's the mentality of Vale, it seems. 'Just bring in new guys, who cares?'

Matt (age 31), as well, reasoned,

I guess in Brazil you can pay people two dollars a day and that. This is Canada though, but they don't get that, I guess.

In these examples and others like them, Vale's workers in less-developed countries are depicted 
as agentless, and often used to demonstrate rhetorically what workers hope to prevent Vale from accomplishing in Sudbury. These national contrasts lump employers and workers together, framing the clash as one between national standards rather than between a multinational conglomerate and a workforce spread throughout many countries (King, 2017).

Spatially restricted forms of solidarity can also emerge among workers who hold these types of views about Global South workers. As Johns (1998) captures through the concept of accommodationist solidarity, such feelings be can self-motivated in that they aim to reduce the attractiveness of capital flight by reducing the wage disparities across an unevenly developed global economy. According to Lévesque and Murray (2010), such an instrumental view of international solidarity can take shape partly through efforts to protect past union gains at home. In the case of Sudbury, the context is somewhat more complex. First, rather than attempting to prevent capital flight, workers are in the position of resisting a foreign multinational from a Global South country with significant capital investments in the Global North. Additionally, because of the spatial fixity of nickel mining in Sudbury, workers are not in the same direct competition with counterparts in other countries where Vale has operations. Under these conditions, we would expect to see less self-interested accommodationist solidarity. Yet, this is not necessarily the case. Workers generate meaningful explanations for the material conditions they face by drawing on popular discourses which seem to confirm their experiences. Workers draw on narratives about outsourcing, off-shoring and globalisation in ways that fit their own experiences into narratives with popular currency, even when these do not necessarily offer an adequate appraisal of conditions at their workplace.

In this view, competition stems as much from foreign workers as it does foreign capital. In narratives such as these, workers in the Global South are sometimes represented as a contagion because of their low wages and less desirable working conditions. Foreign investment brings with it the dangers of low wages and culturally backward standards in the realms of industrial relations and labour standards.

\section{National identity, industrial relations and union strategy}

I understand interviewees' use of national identity also as a narrative strategy that has been shaped by the political economy of post-war capitalism and Fordist industrial relations. In part, the nation is available to workers as an identifiable social category because of the legacy of nationally regulated welfare capitalism and the way that the nation-state integrated the working class into the post-war settlement as "industrial citizens" who gained rights and privileges through a state-administered system of collective bargaining and union security (Fudge, 2005).

Spatially bound working classes have made gains and won reforms mostly through their respective nation-states. It is at this level that workers have been able to exercise countervailing powers and rights against capital in the forms of collective bargaining rights, national welfare states and other reformist policy victories. As Seccombe and Livingstone (2000: 35) argue, this has consequently made workers more dependent on the nation-state against the powers of both national and multinational corporate power. In the interviews, workers often express this sentiment as a set of expectations that the federal and provincial governments in Canada should protect workers against foreign-based, multinational corporations. Brad (age 31) remarked:

Canada just seems to let any foreign company who wants to invest in here, don't matter how they treat the workers.

Alain, reflecting on a previous union campaign aimed at bringing Inco under public control 
rather than allowing it to be purchased, surmised:

It was foolish, in my opinion. We could have owned it [Inco] outright. Government could have stepped in to keep good Canadian jobs and prevent a foreign corporation from coming in here and acting like this.

Such comments carry with them a critical and latently transformative framing of the issues at stake, yet in their frequent attachment to a discourse of nationalism, workers also tend toward unhelpful characterisations of potential allies in the Global South as well as an overestimation of what governments in Canada have been and are currently willing to countenance as policies or proposals which might aid workers. As Dale concluded,

We're Canadian workers, just want to be treated with the kind of respect, you know, at a level we should be. Vale, they don't want no part of that (emphasis his).

Brecher et al. (2006) make a similar point concerning the legacy of national institutions in shaping working-class agency. They point out that expanding union activity globally runs up against institutional obstacles such as the rules and limitations imposed through national industrial relations systems. The legal complexity and variation between nation-states' systems of labour law can be significant obstacles to engaging in the types of disruptive collective action which might coordinate and increase global working-class power. Additionally, issues over which workers may struggle and bargain vary across national space. For instance, health care and vacations - issues which are addressed through collective bargaining (at the worksite or sectoral level) in one country - are provided for through national social policies in another. Further, as Lévesque and Murray (2002) point out, the globalisation of production generates particular structural obstacles for unions in decentralised bargaining regimes, such as Canada's, where spatial coordination even within the nation is difficult.

In many respects, the practices and strategic repertoires of unions are embedded within national and subnational state institutions and, consequently, unionised workers' identities are shaped by the regulated exercise of trade union rights. For many workers, the collective memory of union struggle revolves around various strikes which appear almost ritualistic in many narratives. As one worker remarked,

When the signs come out and the gates, and you get to the same familiar [picket] lines, and the routine of it, right, it sort of all comes back to you.

Class struggle is organised, regulated and ultimately contained within the nation-state (or the province in Canada). Yet, it is precisely this geographical and institutional containment which also provides to workers as a trade-off the rights and material gains which they seek to protect (Munck, 2010). In this way, it is unsurprising that defensive class struggles in an era of greater global capitalist integration will at times find nationalistic expression, which is not to excuse its often problematic and racialised inflections.

As Seeliger (2016) shows, national institutional and regulatory frameworks can also shape workers' perceptions of effective union strategy. Workers may evaluate courses of action and the possibilities for success based on past experiences, which are, inevitably, shaped by how institutional arrangements and class struggle have interacted. The ways in which past class interests, structured by institutional relations and regularised union activity, can continue to influence how workers understand their current confrontations with employers, as well as the 
available repertoires of collective action which they might take to address their issues (see also Bolsmann, 2010). In the case of workers employed by Vale in countries with different levels of economic development and state capacity, national variation also impacts the political forms of union activity. Dale, in talking about his experience at events organised by his union which saw Vale employees from Brazil, Mexico and Mozambique visit Sudbury, mentions how these workers seemed critical of his union local's organising methods:

I was talking to a couple Brazilian guys and I definitely got the impression that they do things a lot different down there, the unions I mean. He didn't understand why we weren't downtown fighting for poor people and that. It was a strange thing to me, weird question. I was like, 'Well, I know the Local gives to the United Way'. But yeah, these guys had the idea basically that 'union' means a lot more than just workers at a mine. [pause] Couple of them didn't seem to think much of how we do things.

Dale reported being genuinely surprised by these conversations, while also somewhat provoked by his interlocutors' criticism of union practice in Sudbury. Such stories highlight some of the institutional impediments to workers imagining and building international solidarity. In some cases, workers found it difficult to imagine what they and their union could do, given the structures of collective bargaining in Canada and labour laws in each nation-state. In Dale's example, the narrow focus of his own union perplexed workers from countries in which social movements and unions have much closer relationships, and where union activity is less focused on the patterned practices of collective bargaining and the administration of union contracts.

In some respects, the criticism that Dale reported other Vale workers from the Global South levelling at his union local have proven somewhat correct. Although USW 6500 continues some global solidarity work, as relations with Vale eased going into the 2015 round of collective bargaining, fewer resources and less effort were directed toward this type of organising. Indeed, USW 6500 and Vale concluded contract negotiations ahead of schedule in 2015, an unsurprising development when considered against the substantive concessions extracted by Vale when the 2010 strike ended.

\section{Conclusion}

This article has sought to explore some of the impediments to international solidarity as they arose in the narratives of unionised nickel miners at Vale during field research in Sudbury, Ontario. Through a close qualitative analysis of interviewee transcripts, the article has aimed to identify the ways in which class identity has been shaped by the institutional and historical legacy of trade unionism in the region, and the ways this complicates union efforts to build solidarity with Vale workers in the Global South.

The findings suggest that attempts to discursively reframe workers' struggle against their new multinational employer have yet to fully contend with the persistence of spatially bound forms of working-class identity and interests. This may be a significant contradiction for union leaders and members to overcome. As Lévesque and Murray (2002: 52) argue, internal solidarity within unions is a means for solidifying collective identity. Yet, the union's ability to reframe issues and reorient notions of collective identity - to change the discursive frame (Hrynyshyn and Ross, 2011) - can also be constrained by this same internal member solidarity and its durable forms of spatially restrictive class identity. Internal solidarity, in other words, can be a limiting factor when one of its primary effects is to solidify a relatively narrow in-group identity. 
Brecher et al. (2006) offer a list of helpful "concrete" activities in which unions should engage to build effective international union alliances, prioritising regular communication and information sharing, worker-to-worker exchanges, offering concrete services and engaging in solidarity support in identifiable campaigns. Workers in this study generally spoke favourably about such activities, but also used stories from meetings with Vale workers from the Global South to further illustrate the fears they had about how a "Third World employer" would affect their working conditions and material well-being. Without ideological leadership and theoretical contextualisation, rank-and-file workers may draw lessons from such worker-to-worker exchanges not intended by union leadership. In this case, workers interviewed in this study tended to use the stories of Global South workers as cautionary tales to buttress their arguments against allowing foreign ownership to undermine "Canadian" labour standards. Ultimately, efforts to reframe class identity and to build durable forms of international solidarity in the mining industry will likely require sustained institution building and commitment from union leaders and rank-and-file activists across borders. Additionally, union leaders should heed Brecher et al.'s (2006) suggestions and - to the greatest extent possible - find ways to link international solidarity work with the concrete material conditions and experiences of rank-and-file union members.

\section{REFERENCES}

Anner, M.S. (2011) Solidarity Transformed: Labor Responses to Globalization and Crisis in Latin America. Ithaca, NY: ILR Press.

Aguzzoli, R. and J. Geary (2014) An "Emerging Challenge": The Employment Practices of a Brazilian Multinational Company in Canada. Human Relations, 67(5): 587-609.

Bischoping, K. and A. Gazso (2016) Analyzing Talk in the Social Sciences: Narrative, Conversation and Discourse Strategies. London: SAGE.

Black, S. (2018) Community Unionism without the Community? Lessons from Labor-Community Alliances in the Canadian Child Care Sector. Labor Studies Journal, 43(2): 118-140.

Bolsmann, C. (2010) Contesting Labor Internationalism: The "Old" Trapped in the "New" in Volkswagen's South African Plant. Labor Studies Journal, 35(4): 520-539.

Brasch, H. (2010) Winds of Change: The Local 6500 USW Strike of 2009 to 2010. Sudbury: Self-published.

Brecher, J., T. Costello and B. Smith (2006) International Labor Solidarity: The New Frontier. New Labor Forum, 15(1): 8-18.

Bronfenbrenner, K., S. Friedman, R.W. Hurd, R.A. Oswald and R.L. Seeber (eds.) (1998) Organizing to Win: New Research on Union Strategies. Ithaca, NY: Cornell University Press.

Bronfenbrenner, K. and T. Juravich (1998) It Takes More than House Calls: Organizing to Win with a Comprehensive Union-building Strategy. In Organizing to Win: New Research on Union Strategies, edited by K. Bronfenbrenner, S. Friedman, R.W. Hurd, R.A. Oswald and R.L. Seeber. Ithaca, NY: Cornell University Press.

Burawoy, M. (2010) From Polanyi to Pollyanna: The False Optimism of Global Labor Studies. Global Labour Journal, 1(2): 301-313.

Buse, D.K. (1993) The 1970s. In Sudbury: Rail Town to Regional Capital, edited by C.M. Wallace and A. Thomson. Toronto: Dundurn.

Calhoun, C. (2012) The Roots of Radicalism: Tradition, the Public Sphere, and Early Nineteenth-Century Social Movements. Chicago: University of Chicago Press.

Camfield, D. (2011) Canadian Labour in Crisis: Reinventing the Workers' Movement. Halifax: Fernwood. 
Cotton, E. and R. Gumbrell-McCormick (2012) Global Unions as Imperfect Multilateral Organizations: An International Relations Perspective. Economic and Industrial Democracy, 33(4): 707-728.

Cowie, J. (1999) Capital Moves: RCA's 70-Year Quest for Cheap Labor. Ithaca, NY: Cornell University Press.

Deneault, A. and W. Sacher, translated by F.A. Reed and R. Philpot (2012) Imperial Canada Inc:: Haven of Choice for the World's Mining Industries. Vancouver: Talon Books.

Dunk, T.W. (2003) It's a Working Man's Town: Male Working-Class Culture. Second edition. Montreal and Kingston: McGill-Queen's University Press.

Ellem, B. (2006) Scaling Labor: Australian Unions and Global Mining. Work, Employment and Society, 20(2): 369-387.

Ellem, B. (2016) Geographies of the Labour Process: Automation and the Spatiality of Mining. Work, Employment and Society, 30(6): 932-948.

Evans, P. (2010) Is it Labor's Turn to Globalize? Twenty-first Century Opportunities and Strategic Responses. Global Labour Journal, 1(3): 350-379.

Evans, P. (2014) National Labor Movements and Transnational Connections: Global Labor's Evolving Architecture Under Neoliberalism. Institute for Research on Labor and Employment, Working Paper No. 116-14 (September). Berkeley, CA: IRLE.

Fantasia. R. and K. Voss (2004) Hard Work: Remaking the American Labor Movement. Berkeley, CA: University of California Press.

Filho, R.F. and L.M. e Silva (2019) From Global Unions to the Shop Floor: Trade Union Networks in Transnational Corporations in Brazil. Global Labour Journal, 10(3): 192-208.

Fontes, V. and A. Garcia (2014) Brazil's New Imperial Capitalism. Socialist Register, 50: 207-226.

Frundt, H.J. (2005) Movement Theory and International Labor Solidarity. Labor Studies Journal, 30(2): 1940.

Fudge, J. (2005) After Industrial Citizenship: Market Citizenship or Citizenship at Work? Relations industrielles/Industrial Relations, 60(4): 631-656.

Hall, A. (1993) The Corporate Construction of Occupational Health and Safety: A Labour Process Analysis. The Canadian Journal of Sociology, 18(1): 1-20.

Harvey, D. (1995) Militant Particularism and Global Ambition: The Conceptual Politics of Place, Space, and Environment in the Work of Raymond Williams. Social Text, 42 (Spring): 69-98.

Harvey, D. (2006) The Limits to Capital. London: Verso.

Herod, A. (2001) Labor Internationalism and the Contradictions of Globalization: Or, Why the Local is Sometimes Still Important in a Global Economy. Antipode, 33(3): 407-426.

Hrynyshyn, D. and S. Ross (2011) Canadian Autoworkers, the Climate Crisis, and Contradictions of Social Unionism. Labor Studies Journal, 36(1): 5-36.

Johns, R.A. (1998) Bridging the Gap Between Class and Space: U.S. Worker Solidarity with Guatemala. Economic Geography, 74(3): 252-271.

Kellogg, P. (2019) Find the Axis of Solidarity: Populist Protectionism and the End of the North American Free Trade Agreement. Studies in Political Economy, 100(1): 65-81.

King, A.D.K. (2017) Memory, Mobilization, and the Social Bases of Intra-union Division: Some Lessons from the 2009-2010 USW 6500 Strike in Sudbury, Ontario. E-Journal of International and Comparative Labour Studies, 6(3): 53-72.

King, A.D.K. (2019) Gender and Working-class Identity in Deindustrializing Sudbury, Ontario. The Journal of Working-class Studies, 4(2): 79-101.

Kumar, P. and C. Schenk (eds.) (2005) Paths to Union Renewal: Canadian Experiences. Toronto: University of Toronto Press. 
Leadbeater, D. (2008) Introduction: Sudbury's Crisis of Development and Democracy. In Mining Town Crisis: Globalization, Labour and Resistance in Sudbury, edited by D. Leadbeater. Halifax: Fernwood.

Lévesque, C. and G. Murray (2002) Local versus Global: Activating Local Union Power in the Global Economy. Labor Studies Journal, 27(3): 39-65.

Lévesque, C. and G. Murray (2010) Local Union Strategies in Cross-border Alliances. Labor Studies Journal, 35(2): 222-245.

Marshall, J. (2015) Behind the Image of South-South Solidarity at Brazil's Vale. In BRICS: An AntiCapitalist Critique, edited by P. Bond and A. Garcia. Chicago: Haymarket.

McAlevey, J.F. (2016). No Shortcuts: Organizing for Power in the New Gilded Age. New York: Oxford University Press.

Munck, R. (2010) Globalization and the Labour Movement: Challenges and Responses. Global Labour Journal, 1(2): 218-232.

Needleman, R. (2008) The Steelworkers Union Goes Global. New Labor Forum, 17(2): 82-90.

Peters, J. (2010) Down in the Vale: Corporate Globalization, Unions on the Defensive, and the USW Local 6500 Strike in Sudbury, 2009-2010. Labour/LeTravail, 66 (Fall): 73-105.

Robinson, D. (2005) The Mining Supply and Service Sector: Innovation Policies and the Delivery Gap. Institute for Northern Ontario Research and Development Working Paper Series. http://inord.laurentian.ca/ 10 05/Delivery \%20Gap.pdf (accessed 18 November 2018).

Ross, S. (2008) Social Unionism and Membership Participation: What Role for Union Democracy? Studies in Political Economy, 81 (Spring): 129-157.

Saarinen, O.W. (2013) From Meteorite Impact to Constellation City: A Historical Geography of Greater Sudbury. Waterloo: Wilfrid Laurier University Press.

Seccombe, W. and D.W. Livingstone (2000) "Down to Earth People": Beyond Class Reductionism and Postmodernism. Aurora: Garamond.

Seeliger, M. (2016) "Forward and Not Forgetting" - How do Workers' Memories Impact International Solidarity? Global Labour Journal, (7)1: 50-68.

Seidman, G.W. (2009) Beyond the Boycott: Labor Rights, Human Rights, and Transnational Activism. New York: SAGE.

Silver, B.J. (2003) Forces of Labor: Workers' Movements and Globalization since 1870. Cambridge: Cambridge University Press.

Stanford, J. (2008) Staples, Deindustrialization, and Foreign Investment: Canada's Economic Journey Back to the Future. Studies in Political Economy, 82 (Autumn): 7-34.

Statistics Canada (2016) Census Profile, Census 2016: Sudbury. https://www12.statcan.gc.ca/censusrecensement $/ 2016 / \mathrm{dp}$-pd/prof/details/page.cfm?Lang $=E \& G e o 1=P O P C \& C o d e 1=0904 \& G e o 2$ $=$ PR\&Code2 $=35 \& D a t a=$ Count $\&$ Search Text $=$ Sudbury\&SearchType $=$ Begins \&SearchPR $=01 \& B 1=A l l$ $\underline{\& G e o L e v e l=P R \& G e o C o d e=0904 \& T A B I D=1}$ [accessed 16 December 2018].

Swift, J. (1977) The Big Nickel: Inco at Home and Abroad. Kitchener: Between the Lines.

Thomas, M.P. (2011) Global Industrial Relations? Framework Agreements and the Regulation of International Labor Standards. Labor Studies Journal, 36(2): 269-287.

Thomas, M.P. and S. Tufts (2016) Austerity, Right Populism, and the Crisis of Labour in Canada. Antipode, 48(1): 212-230.

Tilly, C. (1995) Globalization Threatens Labor's Rights. International Labor and Working-Class History, 47 (Spring): 1-23.

United Steelworkers of America (1987) Technological Change at Inco and Its Impacts on Workers: A Study Sponsored by Local 6500. Sudbury and Pittsburgh: USWA. 
Vale (2018) Vale's Production and Sales in 1Q18. Investor Relations Department: Vale. http://www.vale.com/EN/aboutvale/reports/3t18/Pages/default.aspx [accessed 18 November 2018].

\section{BIOGRAPHICAL NOTE}

AdAM D.K. KING is Postdoctoral Visitor in the Politics Department at York University in Toronto, Ontario. His research examines work and labour in the nickel mining industry. Currently, he is part of a team of researchers studying labour standards enforcement in Canada's federal jurisdiction, as well as the contested regulation of indigenous labour relations in Canada. [email: adkking2@yorku.ca] 